\title{
PENDAPATAN DAN RISIKO USAHATANI PADI ORGANIK DAN NON ORGANIK DI KARANGASEM, KETAPANG, SUSUKAN, KABUPATEN SEMARANG
}

\author{
(The Income and risk of organic and non-organic rice farming in Karangasem, Ketapang \\ Village, Susukan District, Semarang Regency) \\ Mayasari Dwi Rahayu' ${ }^{1}$, Yuliawati ${ }^{2}$ \\ Fakultas Pertanian dan Bisnis, Universitas Kristen Satya Wacana Salatiga \\ Email : 522015012@student.uksw.edu¹,yuliawati.fpb@uksw.edu ${ }^{2}$
}

Article Submitted : 23-11-2019

Article Accepted : 07-02-2020

\begin{abstract}
The main commodity of crops that most contributes to agricultural development is rice. The purpose of this research was to determine differences in income, differences in the value of production and income risk, as well as the effect of production factors on the risk of production of organic and non-organic rice farming in Karangasem, Ketapang Village, Susukan District, Semarang Regency. The sampling technique is simple random sampling. Determination of the number of samples with the Slovin formula, obtained 89 farmers as respondents consisting of 44 organic farmers and 45 non-organic farmers. Income differences were analyzed using the average difference test, to determine differences in the value of production risk and income using the coefficient of variation $(\mathrm{CV})$, while to determine the effect of production factors on production risk using multiple linear regression analysis. The results showed that organic rice farming income (Rp. 7,872,844) was greater than non-organic rice farming income (Rp $4,963,953)$ with a difference $(\operatorname{Rp} 2,908,891)$ and was significantly different. Based on the value $(\mathrm{CV})$, the risk of organic rice farming production is 0.27 higher than the value (CV) of nonorganic rice farming 0.21 . The value $(\mathrm{CV})$ of non-organic rice farming income risk is 1.01 higher than the value $(\mathrm{CV})$ of organic rice farming of 0.85 . Production factors that influence the risk of organic rice farming production are labor, and for non-organic rice farming is synthetic fertilizer.
\end{abstract}

Keywords : Organic; non-organic; income; $C V$; production risk.

\section{PENDAHULUAN}

Komoditas utama sektor pertanian yang banyak ditanam oleh petani adalah padi, komoditas tersebut merupakan penyedia kebutuhan pokok berupa beras. Banyak konsumen beras yang mulai memilih mengkonsumsi beras organik, terjadi peningkatan sekitar $22 \%$ setiap tahunnya untuk permintaan pasar beras organik dengan besarnya pasar yang mencapai 28 miliar rupiah pada tahun 2005 (Wulandari, 2011). Rahayuningsih et al. (2016) menyatakan terjadi peningkatan permintaan beras organik di Boyolali sebesar 1.128,5 ton atau $48 \%$ dari tahun 2013-2014. Harga jual beras organik juga lebih tinggi jika dibandingkan dengan harga beras non organik dengan rata-rata selisih harga dari tahun 2010-2014 yang mencapai Rp 3.077 per kg. Permintaan beras organik yang semakin meningkat serta lebih tingginya harga jual beras organik mampu mempengaruhi pendapatan petani padi organik.

Permintaan terhadap beras organik meningkat namun petani di Indonesia masih ragu untuk beralih ke sistem budidaya pertanian secara organik dengan pertimbangan risiko usahatani dari sistem organik tersebut. Masalah risiko berkenaan 
dengan sifat usahatani yang bergantung pada kondisi alam. Risiko produksi dalam budidaya padi dapat terjadi dikarenakan adanya bermacam-macam faktor produksi yang digunakan (Suharyanto, Rinaldy \& Arya, 2015).

Analisis pendapatan serta kajian risiko usahatani padi organik dan non organik yang dilakukan berusaha menjawab keingintahuan apakah di tempat penelitian terjadi fenomena yang sama dengan hasil penelitian sebelumnya mengenai perbedaan besarnya pendapatan dan nilai risiko antara usahatani padi organik dan non organik, sehingga hasil analisis dapat dijadikan sebagai bahan masukan untuk petani di daerah penelitian. Dari uraian latar belakang di atas penelitian ini bertujuan untuk mengetahui perbedaan pendapatan, perbedaan nilai risiko produksi dan pendapatan, serta pengaruh faktor produksi terhadap risiko produksi usahatani padi organik maupun non organik di Karangasem, Ketapang, Susukan, Kabupaten Semarang.

\section{METODE PENELITIAN}

Lokasi penelitian berada di Dusun Karangasem Desa Ketapang Kecamatan
Susukan Kabupaten Semarang. Pemilihan lokasi ditentukan secara purposive dengan pertimbangan terdapat petani padi organik dan non organik. Penelitian ini dilaksanakan pada bulan April 2019 s/d Juni 2019. Penelitian deskriptif kuantitatif ini menggunakan teknik penarikan sampel secara simple random sampling. Penentuan jumlah sampel dengan rumus Slovin dan didapatkan 89 petani responden yang terdiri dari 44 petani organik dan 45 non organik.

Perhitungan pendapatan usahatani padi organik maupun usahatani padi non organik dilakukan dengan perhitungan menggunakan rumus sebagai berikut : $\Pi=\mathrm{TR}-\mathrm{TC}$

Keterangan: $\Pi=$ Keuntungan $(\mathrm{Rp})$

$$
\begin{aligned}
& \mathrm{TR}=\text { Penerimaan }(\mathrm{Rp}) \\
& \mathrm{TC}=\text { Biaya tetap }+ \text { Biaya } \\
& \text { variabel }(\mathrm{Rp})
\end{aligned}
$$

Setelah diketahui besarnya pendapatan lalu dilakukan uji beda rata-rata antara pendapatan usahatani padi organik dengan usahatani padi non organik. Hipotesis dari uji beda rata-rata adalah $\mathrm{H}_{0}: \mu_{1} \leq \mu_{2}$ lawan $\mathrm{H}_{1}: \mu_{1}>\mu_{2}$

Keterangan :

$\mu_{1} \quad=$ Pendapatan usahatani padi organik

$\mu_{2} \quad=$ Pendapatan usahatani non organik

Kriteria pengujian untuk mengetahui perbedaan pendapatan adalah apabila $t_{\text {hit }} \leq t_{\text {tab }} \rightarrow$ tidak berbeda (H0 diterima), $\mathrm{t}_{\text {hit }}>\mathrm{t}_{\mathrm{tab}} \rightarrow$ berbeda (H0 ditolak).

Analisis nilai risiko menggunakan koefisien variasi (CV) yang merupakan ukuran risiko relatif, secara sistematis dirumuskan sebagai berikut:
a) Risiko Pendapatan
b) Risiko Produksi
Keterangan :
$\mathrm{CV}=\frac{V a}{E 1}$
$\mathrm{CV}=\frac{V b}{E 2}$

$\mathrm{CV}=$ Koefisien variasi

$\mathrm{E} 1=$ Pendapatan rata-rata $(\mathrm{Rp} / \mathrm{Ha})$

$\mathrm{Va}=$ Standar deviasi pendapatan $(\mathrm{Rp} / \mathrm{Ha})$

$\mathrm{Vb}=$ Standar deviasi produksi $(\mathrm{Kg} / \mathrm{Ha})$

Besarnya pengaruh input terhadap produksi dan risiko produksi usahatani padi organik dan non organik dianalisis Persamaan Fungsi Produksi:

In $Y($ or $)=a+a_{1} \ln X 1+a_{2} \ln X 2+a_{3} \ln X 3+a_{4} \ln X 4+a_{5} \ln X 5+u_{1}$ (or).

In $Y($ nor $)=b+b_{1} \ln X 1+b_{2} \ln X 2+b_{3} \ln X 3+b_{4} \ln X 4+b_{5} \ln X 5+u_{1}$ (nor).

Nilai mutlak residual $|\mathrm{u}|$ yang diperoleh dari persamaan fungsi produksi digunakan untuk membuat persamaan fungsi risiko produksi

Persamaan Fungsi Risiko Produksi:

$$
\mid u_{1}(\text { or }) \mid=c+c_{1} \ln X 1+c_{2} \ln X 2+c_{3} \ln X 3+c_{4} \ln X 4+c_{5} \ln X 5+u_{2}(\text { or }) .
$$




$$
\mid u_{1}(\text { nor }) \mid=d+d_{1} \ln X 1+d_{2} \ln X 2+d_{3} \ln X 3+d_{4} \ln X 4+d_{5} \ln X 5+u_{2} \text { (nor). }
$$

Keterangan:

In $Y($ or $) \quad=$ Produksi padi organik dalam bentuk beras $(\mathrm{kg} / \mathrm{ha})$

In $Y$ (nor) $=$ Produksi padi non organik dalam bentuk beras $(\mathrm{kg} / \mathrm{ha})$

$\ln X 1 \quad=$ Benih $(\mathrm{kg} / \mathrm{ha})$

$\ln X 2=$ Pupuk Kandang $(\mathrm{kg} / \mathrm{ha})$

$\ln X 3 \quad=$ Organik $\quad$ : Pupuk Organik Cair $(\mathrm{POC})(\mathrm{Rp} / \mathrm{ha})$

$\ln X 4 \quad=$ Pestisida $(\mathrm{Rp} / \mathrm{ha})$

$\ln X 5 \quad=$ Tenaga Kerja $(\mathrm{HOK} / \mathrm{ha})$

$a, b, c, d \quad=$ Intersep

$a_{i}, b_{i,} c_{i}, d_{i}=$ Koefisien

$\mathrm{u} \quad=$ Residual

$\mid u_{1}($ or $) \mid=$ Risiko Produksi Organik

$\mid u_{1}$ (nor) $\mid=$ Risiko Produksi Non organik

Uji statistik terhadap model yaitu uji koefisien determinasi $\left(\mathrm{R}^{2}\right)$, Uji F dan Uji-t.

HASIL PEMBAHASAN

\section{Struktur Biaya dan Pendapatan Usahatani padi Organik dan Non Organik}

Analisis pendapatan yang dilakukan dalam penelitian ini merupakan selisih penerimaan dengan biaya tetap dan biaya variabel, usahatani dapat dikatakan berhasil apabila jumlah penerimaan lebih besar dibandingkan dengan jumlah biaya yang telah dikeluarkan (Wulandari, 2011). Tabel 1 adalah tabel struktur biaya usahatani padi organik dan non organik .

Tabel 1 Struktur biaya usahatani padi organik dan non organik per hektar per musim tanam

\begin{tabular}{|c|c|c|c|c|c|c|}
\hline & \multirow{2}{*}{ Komponen Biaya } & \multicolumn{2}{|c|}{ Padi Organik } & \multicolumn{2}{|c|}{ Padi Non Orgaik } & \multirow{2}{*}{ Uji t } \\
\hline & & Nilai (Rp/ha) & $(\%)$ & Nilai (Rp/ha) & $(\%)$ & \\
\hline \multirow[t]{4}{*}{ A. } & Biaya Tetap & & & & & \\
\hline & Penyusutan alat & 130.422 & 0,84 & 123.600 & 0,71 & $0,664^{\mathrm{ns}}$ \\
\hline & Pajak & 427.749 & 2,74 & 502.015 & 2,88 & $0,060^{*}$ \\
\hline & Traktor & 1.982 .035 & 12,72 & 1.508 .444 & 8,65 & $0,279^{\text {ns }}$ \\
\hline \multicolumn{2}{|c|}{ Sub Total } & 2.540 .206 & 16,30 & 2.134 .059 & 12,24 & \\
\hline \multirow[t]{8}{*}{ B. } & Biaya Variabel & & & & & \\
\hline & Benih & 498.170 & 3,20 & 484.220 & 2,78 & $0,720^{\text {ns }}$ \\
\hline & Pupuk Kandang & 1.218 .492 & 7,82 & 892.309 & 5,11 & $0,000^{* * *}$ \\
\hline & Pupuk Organik Cair & 550.947 & 3,53 & 0 & 0 & \\
\hline & Pupuk Sintetis & 0 & 0 & 1.661 .444 & 9,52 & 0,000 \\
\hline & Pestisida Organik & 68.939 & 0,44 & 0 & 0 & \\
\hline & Pestisida Sintetis & 0 & 0 & 453.808 & 2,60 & 0,000 \\
\hline & Tenaga Kerja & 10.710 .849 & 68,71 & 11.820 .207 & 67,75 & $0,047^{* *}$ \\
\hline \multicolumn{2}{|c|}{ Sub Total } & 13.047 .397 & 83,70 & 15.311 .988 & 87,76 & \\
\hline \multicolumn{2}{|c|}{ Total Biaya } & 15.587 .603 & 100,00 & 17.446 .047 & 100,00 & $0,001^{* * *}$ \\
\hline
\end{tabular}

Total biaya usahatani padi non organik $\mathrm{Rp}$ 17.446.047/Ha lebih besar dari total biaya usahatani padi organik Rp 15.587.603/Ha. Ada perbedaan secara nyata terhadap biaya pajak lahan, pupuk, pestisida dan biaya tenaga kerja.

Perbedaan besarnya pajak lahan yang dibayarkan oleh petani didasarkan pada Nilai Jual Objek Pajak (NJOP) yaitu harga rata-rata 
tingkat pasar pada transaksi jual beli tanah (Kemenkeu, 2018). Biaya pajak lahan usahatani padi non organik Rp 502.015/Ha $(2,88 \%)$ berbeda dibanding pajak lahan usahatani padi organik Rp 427.749/Ha (2,74\%). Biaya pupuk kandang usahatani padi organik lebih tinggi $\mathrm{Rp} 1.218 .492 / \mathrm{Ha}$ $(7,82 \%)$ dibanding usahatani padi non organik Rp 892.309/Ha (5,11\%) perbedaan biaya dikarenakan usahatani padi organik berimplikasi pada penggunaan pupuk kandang yang lebih banyak sehingga menuntut biaya pupuk kandang yang lebih besar. Biaya pestisida usahatani padi non organik Rp 453.808/Ha (2,60\%) berbeda dan lebih besar dari biaya pestisida usahatani padi organik Rp 68.939/Ha (0,44\%), sejalan dengan penelitian Nasution, Rulianda, \& Emalissa (2018) biaya pestisida usahatani padi non organik lebih besar karena jenis pestisida yang digunakan lebih beragam, berbeda dengan usahatani padi organik, pestisida yang digunakan merupakan hasil pembuatan sendiri sehingga bisa menekan biaya. Biaya tenaga kerja secara nyata berbeda dimana biaya tenaga kerja usahatani padi organik $\mathrm{Rp} 10.710 .849 / \mathrm{Ha}(68,71 \%)$ lebih rendah dari biaya tenaga kerja usahatani padi non organik Rp 11.820.207/Ha $(67,75 \%)$. Biaya tetap dan biaya variabel dalam penelitian ini digunakan untuk menganalisis perbandingan pendapatan yang diuraikan sebagai berikut.

Tabel 2. Perbandingan pendapatan usahatani padi organik dan non organik per hektar per musim tanam.

\begin{tabular}{|c|c|c|c|}
\hline No & Uraian & Padi Organik (Rp/Ha) & Padi Non Orgaik (Rp/Ha) \\
\hline 1 & Penerimaan & 23.460 .448 & 22.415 .037 \\
\hline \multirow[t]{4}{*}{2} & Biaya & & \\
\hline & - Biaya Tetap & 2.540 .206 & 2.134 .059 \\
\hline & - Biaya Variabel & 13.047.397 & 15.311 .988 \\
\hline & Biaya Total & 15.587 .603 & 17.446 .047 \\
\hline \multirow[t]{2}{*}{3} & Pendapatan & 7.872 .845 & 4.968 .990 \\
\hline & Uji t Pendapatan & & $0,023^{* *}$ \\
\hline
\end{tabular}

Pendapatan usahatani padi organik lebih besar Rp 7.872.845/Ha dibanding usahatani non organik Rp 4.968.990/Ha, perbedaan tersebut secara nyata juga berbeda apabila dilihat dari hasil uji Independn Sample T-test yaitu $0,023^{* *}<0,05$. Perbedaan pendapatan ini

\section{Analisis Nilai Risiko Produksi dan Nilai Risiko Pendapatan}

Koefisien variasi (CV) digunakan untuk menganalisis risiko produksi dan risiko pendapatan, lalu dilakukan perbandingan nilai risiko antara usahatani padi organik dengan usahatani padi non organik. Besar kecilnya nilai koefisien variasi (CV) sejalan dengan hasil penelitian Mutiarasari (2016) menyimpulkan bahwa pendapatan atas biaya total usahatani padi organik lebih besar dibandingkan usahatani padi non organik dengan selisih pendapatan sebesar $\mathrm{Rp}$ 6.436.096/Ha.

menggambarkan tinggi rendahnya risiko, apabila nilai $\mathrm{CV}$ tinggi berarti usahatani semakin berisiko begitu juga sebaliknya (Pujiati \& Prihtanti, 2018). Perbandingan risiko produksi dan pendapatan antara usahatani padi organik dengan non organik dapat dilihat pada tabel berikut. 
Tabel 3. Nilai Risiko Pendapatan dan Nilai Risiko Produksi CV

\begin{tabular}{ccc}
\hline Sistem & & Koefisien variasi (risiko) \\
\cline { 2 - 3 } Usahatani & Produksi & Pendapatan \\
\hline Organik & 0,27 & 0,85 \\
Non Organik & 0,21 & 1,01 \\
\hline
\end{tabular}

Berdasarkan analisis Koefisien Variasai (CV), nilai risiko produksi usahatani padi organik 0,27 lebih tinggi dibanding usahatani padi non organik dengan nilai sebesar 0,21 , artinya terdapat variasi produksi yang lebih tinggi pada usahatani padi organik, karena dalam praktiknya usahatani padi organik tidak menggunakan pupuk ataupun pestisida sintetis sehingga penanganan hama tikus yang banyak dikeluhkan oleh petani lebih banyak dilakukan secara alami. Nilai risiko pendapatan, lebih tinggi risiko pendapatan usahatani padi non organik 1,01 jika dibandingkan usahatani padi organik 0,85. Sejalan dengan hasil penelitian yang dilakukan oleh Aprilliani (2015) bahwa harga jual hasil usahatani padi organik yang tinggi menjadikan pendapatan usahatani padi organik lebih tinggi dibandingkan usahatani padi non organik.

\section{Analisis Fungsi Produksi dan Fungsi Risiko Produksi Padi Organik}

Hasil estimasi persamaan fungsi produksi dan fungsi risiko produksi usahatani padi organik dapat dilihat pada Tabel 4. Nilai koefisien determinasi $\left(\mathrm{R}^{2}\right)$ fungsi produksi sebesar 0,526886 menunjukkan 52,68\% variasi produksi dapat dijelaskan oleh variabel bebas yaitu benih, pupuk kandang, POC, pestisida dan tenaga kerja dan sisanya $47,32 \%$ dijelaskan oleh variabel lain di luar model. Nilai $F$-statistic produksi signifikan pada $\mathrm{a}=0,01$, artinya variabel independen secara bersama-sama berpengaruh signifikan terhadap produksi padi organik. Nilai koefisien determinasi $\left(\mathrm{R}^{2}\right)$ fungsi risiko produksi sebesar 0,194379 menunjukkan $19,43 \%$ variasi risiko produksi dapat dijelaskan oleh variabel bebas yaitu benih, pupuk kandang, POC, pestisida, tenaga kerja dan sisanya $80,57 \%$ dijelaskan oleh variabel lain di luar model. Nilai $F$-statistic risiko produksi tidak signifikan, artinya secara bersama-sama variabel independen tidak berpengaruh terhadap risiko produksi usahatani padi organik.

Tabel 4. Analisis Regresi Fungsi Produksi dan Fungsi Risiko Produksi Usahatani Padi Organik

\begin{tabular}{|c|c|c|c|c|c|c|}
\hline \multirow{3}{*}{ Variabel } & \multicolumn{6}{|c|}{ Usahatani Padi Organik } \\
\hline & \multicolumn{3}{|c|}{ Fungsi Produksi } & \multicolumn{3}{|c|}{ Fungsi Risiko Produksi } \\
\hline & Coefficient & & Prob & Coefficient & & Prob \\
\hline $\mathrm{C}$ & 6,721107 & & 0,0000 & $-0,464782$ & & 0,0604 \\
\hline Ln Benih & 0,423677 & $* * *$ & 0,0000 & $-0,014902$ & ns & 0,2927 \\
\hline $\begin{array}{l}\text { Ln Pupuk } \\
\text { Kandang }\end{array}$ & 0,196062 & ** & 0,0366 & 0,002062 & ns & 0,9019 \\
\hline Ln POC & $-0,151667$ & $* * *$ & 0,0100 & 0,002170 & ns & 0,8338 \\
\hline Ln Pestisida & 0,004974 & ns & 0,9525 & 0,019877 & ns & 0,1997 \\
\hline Ln Tenaga Kerja & $-0,095883$ & ns & 0,5818 & 0,059242 & $*$ & 0,0693 \\
\hline R-squared & 0,526886 & & & 0,194379 & & \\
\hline Adj R-squared & 0,464635 & & & 0,088376 & & \\
\hline S.E of regression & 0,226593 & & & 0,041609 & & \\
\hline F-statistic & 8,463795 & $* * *$ & & 1,833712 & $\mathrm{~ns}$ & \\
\hline
\end{tabular}


Input benih secara nyata berpengaruh positif terhadap produksi usahatani padi organik dengan nilai 0,423677 artinya apabila terjadi penambahan 1 (satuan) benih maka akan meningkatkan produksi padi organik sebesar 0,423677 (satuan) dan variabel lain dianggap tetap. Sejalan dengan hasil penelitian Suharyanto, Rinaldy, \& Arya (2015) bahwa benih berpengaruh positif dan nyata terhadap peningkatan jumlah produksi padi sawah. Nilai koefisien regresi penggunaan benih terhadap risiko produksi tidak signifikan, sesuai dengan hasil penelitian Rama (2016) yang menyatakan bahwa benih tidak berpengaruh terhadap risiko produksi padi lahan kering.

Penggunaan pupuk kandang berpengaruh positif dan nyata pada produksi padi organik. Jumlah pupuk yang digunakan oleh petani sebesar $4874 \mathrm{Kg} / \mathrm{Ha}$, lebih besar dari anjuran penggunaan pupuk kandang sebesar 2000 $\mathrm{Kg} / \mathrm{Ha}$ (Hariono, 2017). Penggunaan pupuk kandang berlebih namun secara nyata dalam penelitian ini pupuk kandang masih dapat meningkatkan produksi dari padi organik, hal ini diduga dikarenakan pupuk kandang memiliki sifat slow release yaitu melepas hara tanah secara perlahan serta kontinu sehingga dapat mencegah terjadinya ledakan suplai hara. Penggunaan pupuk kandang tidak signifikan terhadap risiko produksi, artinya tidak ada pengaruh penggunaan pupuk kandang terhadap risiko produksi usahatani padi organik.

Penambahan POC secara nyata dengan tanda negatif berpengaruh terhadap produksi usahatani padi organik dengan nilai 0,151667, dan dapat diartikan bahwa setiap penambahan 1 (satuan) pupuk organik cair

Hasil estimasi persamaan fungsi produksi dan fungsi risiko produksi usahatani padi non organik dapat dilihat pada Tabel 5. Nilai koefisien determinasi $\left(\mathrm{R}^{2}\right)$ fungsi produksi sebesar 0,612999 menunjukkan 61,29\% variasi produksi dapat dijelaskan oleh variabel bebas yaitu benih, pupuk kandang, pupuk sintetis, pestisida dan tenaga kerja dan sisanya $38,71 \%$ dijelaskan oleh variabel lain akan mengurangi sebesar 0,151667 (satuan) produksi. Koefisien regresi POC terhadap risiko produksi tidak signifikan, artinya pupuk organik cair tidak berpengaruh terhadap risiko produksi usahatani padi organik. Rata-rata penggunaan POC di daerah penelitian sekitar 18,3 liter/ha, menurut Wowo (2013) dalam Niis \& Nik (2017) bahwa pemberian pupuk organik cair dengan dosis 12 liter/ha menghasilkan hasil produksi yang paling baik dengan total hasil panen sebesar 7,9 ton/ha. Perlu dilakukan pengurangan penggunaan POC karena pengurangan $\mathrm{POC}$ dapat menambah produksi dan mengurangi risiko.

Penggunaan pestisida organik tidak berpengaruh secara nyata terhadap produksi maupun risiko produksi usahatani padi organik. Pestisida organik merupakan pestisida yang diramu oleh petani dengan menggunakan bahan-bahan alami. Ketidakjelasan kandungan bahan aktif diduga menjadikan pestisida organik tidak memberikan pengaruh terhadap produksi maupun risiko produksi usahatani padi organik.

Tenaga Kerja tidak berpengaruh secara nyata terhadap produksi usahatani padi organik. Koefisien regresi tenaga kerja terhadap fungsi risiko produksi berpengaruh secara signifikan. Adanya pengaruh penambahan tenaga kerja terhadap risiko produksi terjadi karena tenaga kerja yang digunakan belum menjamin dapat menurunkan risiko produksi, rata-rata prnggunaan tenaga kerja didaerah penelitian adalah $159 \mathrm{HOK} / \mathrm{Ha}$.

\section{Analisis Fungsi Produksi dan Fungsi Risiko Produksi Padi Non Organik}

di luar model. Nilai $F$-statistic produksi signifikan pada $\mathrm{a}=0,01$, artinya variabel independen secara bersama-sama berpengaruh signifikan terhadap produksi padi non organik. Nilai $\left(\mathrm{R}^{2}\right)$ fungsi risiko produksi sebesar 0,137291 menunjukkan $13,72 \%$ variasi risiko produksi dapat dijelaskan oleh variabel bebas yaitu benih, pupuk kandang, pupuk sintetis, pestisida, 
tenaga kerja dan sisanya $86,28 \%$ dijelaskan oleh variabel lain diluar model. nilai $\left(\mathrm{R}^{2}\right)$ rendah tidak berarti model regresi jelek karena tujuan regresi bukan semata ingin mendapatkan nilai $\left(\mathrm{R}^{2}\right)$ tinggi, tetapi mencari nilai estimasi koefisien regresi dan menarik inferensi statistic (Yuliawati, 2016). Nilai $F$ statistic risiko produksi tidak signifikan, artinya secara bersama-sama variabel independen tidak berpengaruh terhadap risiko produksi usahatani padi non organik.

Tabel 5. Analisis Regresi Fungsi Produksi dan Fungsi Risiko Produksi Usahatani Padi Non Organik

\begin{tabular}{|c|c|c|c|c|c|c|}
\hline \multirow{3}{*}{ Variabel } & \multicolumn{6}{|c|}{ Usahatani Padi Non Organik } \\
\hline & \multicolumn{3}{|c|}{ Fungsi Produksi } & \multicolumn{3}{|c|}{ Fungsi Risiko Produksi } \\
\hline & Coefficient & & Prob & Coefficient & & Prob \\
\hline $\mathrm{C}$ & $-5,550286$ & & 0,0890 & 0,433876 & & 0,3187 \\
\hline Benih & 0,333783 & *** & 0,0002 & 0,001747 & ns & 0,8757 \\
\hline Pupuk Kandang & 0,187902 & ns & 0,2468 & 0,032568 & ns & 0,1392 \\
\hline Pupuk Sintetis & 0,690991 & *** & 0,0004 & $-0,042281$ & $*$ & 0,0851 \\
\hline Pestisida & 0,084354 & ns & 0,2613 & $-0,003373$ & ns & 0,7375 \\
\hline Tenaga Kerja & $-0,115041$ & ns & 0,5666 & $-0,007365$ & ns & 0,7855 \\
\hline R-squared & 0,612999 & & & 0,137291 & & \\
\hline Adj R-squared & 0,563384 & & & 0,026688 & & \\
\hline S.E of regression & 0,149883 & & & 0,020234 & & \\
\hline F-statistic & 12,35500 & $* * *$ & & 1,241292 & $\mathrm{~ns}$ & \\
\hline
\end{tabular}

Secara nyata penggunaan benih berpengaruh positif terhadap produksi usahatani padi non organik, penambahan 1 (satuan) benih dapat meningkatkan produksi usahatani padi non organik sebesar 0,333783 (satuan). Ini sejalan dengan hasil penelitian Hariono (2017) bahwa benih berpengaruh positif dan nyata terhadap jumlah produksi padi.

Penggunaan pupuk kandang tidak berpengaruh secara nyata terhadap produksi maupun risiko produksi usahatani padi non organik. Pupuk kandang yang digunakan merupakan pupuk hasil pengkomposan, jumlah pupuk kandang yang digunakan oleh petani padi non organik sebesar 3569 $\mathrm{Kg} / \mathrm{Ha}$. Pemberian pupuk kandang tersebut lebih besar dibandingkan dengan anjuran penggunaan pupuk kandang sebesar 2000 $\mathrm{Kg} / \mathrm{Ha}$ (Hariono, 2017). Penambahan pupuk kandang akan lebih baik penggunaannya bila dikomposkan terlebih dahulu, karena apabila digunakan secara langsung pupuk kandang yang mengandung unsur hara dapat menimbulkan panas pada tanaman dan menyebabkan tidak dapat diserapnya unsur hara oleh tanaman bahkan dapat menyebabkan kematian (Chrisdiyanti, 2019).

Penggunaan pupuk sintetis dapat meningkatkan produksi padi non organik. Pupuk sintetis yang digunakan petani yakni pupuk Urea, Phonska, Za, NPK dan Petroganik. Acuan rekomendasi penggunaan pupuk yang dikeluarkan oleh Permentan (2007) untuk daerah penelitian yaitu Kecamatan Susukan yang berada di Provinsi Jawa Tengah yaitu untuk pupuk Urea 275 $\mathrm{Kg} / \mathrm{Ha}$ dan rata-rata penggunaan pupuk Urea yang digunakan di tempat penelitian adalah $345 \mathrm{Kg} / \mathrm{Ha}$. Anjuran penggunaan pupuk Phonska menuruh Hariono (2017) adalah $300 \mathrm{Kg} / \mathrm{Ha}$ dan rata-rata pupuk Phonska yang digunakan $319 \mathrm{~kg} / \mathrm{Ha}$, untuk anjuran penggunaan pupuk $\mathrm{Za}$ adalah $300 \mathrm{Kg} / \mathrm{Ha}$ dan rata-rata pupuk $\mathrm{Za}$ yang digunakan 49 $\mathrm{kg} / \mathrm{Ha}$, anjuran penggunaan Granule 500 $\mathrm{Kg} / \mathrm{Ha}$, rata-rata yang digunakan $37 \mathrm{Kg} / \mathrm{Ha}$. Anjuran penggunaan pupuk NPK adalah 300 $\mathrm{Kg} / \mathrm{Ha}$ Wadu, Yuliawati, \& Nuswantara (2019) dan rata-rata pupuk NPK yang digunakan oleh petani hanya $39 \mathrm{~kg} / \mathrm{Ha}$. 
untuk penggunaan pupuk Za, NPK dan Granule penggunaannya masih dapat ditingkatkan karena masih dapat meningkatkan hasil, untuk penggunaan pupuk ponska sudah mendekati dosis yang dianjurkan, sedangkan untuk penggunaan pupuk Urea melebihi dosis anjuran sehingga harus dikurangi.

Penggunaan pestisida non organik dapat menambah jumlah produksi namun tidak berpengaruh secara nyata terhadap produksi usahatani padi non organik. Pestisida non organik yang digunakan oleh petani banyak sekali macamnya penggunaan pestisida di kalangan petani bervariasi tergantung serangan hama dan penyakit. Hasil analisis terhadap risiko produksi menunjukkan pengaplikasian pestisida tidak berpengaruh secara nyata dengan tanda negatif terhadap risiko usahatani padi non organik. Serangan hama yang paling banyak dikeluhkan oleh petani di daerah penelitian adalah serangan hama tikus, penanganannyapun minim sekali dengan menggunakan racun-racun. Pospit adalah salah satu pestisida yang digunakan untuk mengurangi serangan hama tikus namun tidak semua petani mengaplikasikannya.

Tenaga Kerja tidak berpengaruh secara nyata terhadap produksi maupun risiko produksi usahatani padi non organik, ratarata penggunaan tenaga kerja didaerah penelitian adalah $175 \mathrm{HOK} / \mathrm{Ha}$. Tidak berpengaruhnya tenaga kerja terhadap produksi menurut Chrisdiyanti (2019) dapat terjadi karena tenaga kerja yang digunakan belum menjamin dapat meningkatkan hasil produksi, bisa saja akibat kurangnya pengawasan membuat hasil produksi menjadi menurun. sejalan dengan hasil penelitian yang telah dilakukan oleh Rama, Nurliza, \& Dolorosa (2016) penggunaan tenaga kerja tidak berpengaruh terhadap produksi maupun risiko produksi usahatani padi lahan kering.

\section{KESIMPILAN DAN SARAN}

\section{Kesimpulan}

Terdapat perbedaan pendapatan antara usahatani padi organik dengan usahatani padi non organik, pendapatan usahatani padi organik $\mathrm{Rp} 7.872 .845$ lebih besar dari pendapatan usahatani padi non organik $\mathrm{Rp}$ 4.968.990 dan berbeda secara nyata dengan selisih pendapatan sebesar Rp 2.903.855.

Risiko Produksi usahatani berdasarkan besarnya nilai $\mathrm{CV}$ diketahui lebih berisiko usahatani organik. Nilai CV produksi usahatani organik 0,27 dan non organik 0,21. Risiko pendapatan usahatani berdasarkan besarnya nilai $\mathrm{CV}$ diketahui lebih berisiko usahatani non organik. Nilai CV pendapatan usahatani organik 0,85 dan non organik 1,01.

Faktor produksi yang berpengaruh terhadap risiko produksi padi organik adalah tenaga kerja sedangkan faktor produksi yang berpengaruh terhadap risiko produksi padi non organik adalah pupuk sintetis.

\section{Saran}

Bagi petani dengan sistim budidaya padi non organik didaerah penelitian sebaiknya secara bertahap mencoba beralih kesistim budidaya organik, karena selain ramah lingkungan harga jual produksi padi organik juga lebih tinggi sehingga dapat meningkatkan pendapatan petani.

\section{DAFTAR PUSTAKA}

Aprilliani, R. (2015). Analisis Pendapatan dan Risiko Usaha Tani Padi Organik dan Anorganik di Kabupaten Pringsewu. Skripsi, Bandar Lampung: Universitas Lampung.

Chrisdiyanti, Y. K. (2019). Analisis Pendapatan Usahatani dan FaktorFaktor yang Mempengaruhi Risiko Produksi Bunga Potong Krisan di Desa Duren Kecamatan Bandungan . AGRIKAN, 12 (1): 1-7. 
Hariono. (2017). Faktor-Faktor yang Mempengaruhi Produksi Padi Sawah Organik dan Non Organik Di Kecamatan Muara Bulian Kabupaten Batanghari. Jambi: Fakultas Pertanian Universitas Jambi.

Kemenkeu RI. (2018). Pedoman Penilaian Pajak Bumi dan Bangunan Pedesaan dan Perkotaan. Indonesia: Kementrian Keuangan Republik Indonesia.

Nasution, A. R., Rulianda, \& Emalisa. (2018). Analisis Perbandingan Kelayakan Antara Usahatani Padi Organik dan Padi Non Organik (Kasus : Desa Lubuk Bayas, Kecamatan Perbaungan, Kabupaten Serdang Bedagi). Jurnal On Social Economic Of Agriculture And Agribusines, 9 (4): 1-14.

Niis , A., \& Nik, N. (2017). Pengaruh Dosis dan Frekuensi Aplikasi Pupuk Organik Cair (POC) Terhadap Pertumbuhan Padi . Portal Jurnal Unimor, 2 (1): 4-7.

Permentan. (2007). Acuan Penetapan Rekomendasi Pupuk N, P , Dan K Pada Lahan Sawah Spesifik Lokasi (Per Kecamatan). Mentri Pertanian, 1-257.

Rahayuningsih, P., Prasetyowati, K., Suswadi , \& Mahananto. (2016). Analisis permintaan beras organik di Boyolali. AGRINECA, 16 (2): 48-62.
Rama, R., Nurliza, \& Dolorosa, E. (2016). Analisis Risiko Produksi Usahatani Padi Lahan Basah dan Lahan Kering Di Kabupaten Melawi. Jurnal Sosial Economic of Agriculture, 5 (1): 7388.

Suharyanto, Rinaldy, J., \& Arya, N. N. (2015). Analisis Risiko Produksi Usahatani Padi Sawah di Provinsi Bali. Jurnal Agraris, 1 (2): 70-77.

Wadu, J., Yuliawati, \& Nuswantara, B. (2019). Strategi menghadapi risiko produksi padi sawah di Kabupaten Sumba Timur. Jurnal Ekonomi Dan Bisnis, 22 (2): 231-256.

Wulandari, I. (2011). Analisis Perbandingan Pendapatan Usaha Tani Padi Organik Dengan Padi Anorganik (Kasus : Kelurahan Sindang Barang dan Situ Gede, Kecamatan Bogor Barat). Skripsi, Bogor: Bogor Agricultural University.

Yuliawati. (2016). Produksi, Efisiensi dan Perilaku Petani Terhadap Risiko Produksi pada Usahatani Sayur Semi Organik dan Konvensional di Kabupaten Semarang. Disertasi, Fakultas Pertanian Universitas Gadjah Mada. 